\title{
Bone mineral density in beta thalassemia syndrome in Mosul city
}

\author{
Khalid N. Al-Khero ${ }^{\text {, }}$, Mashaan M. Salih ${ }^{\text {b }}$ \\ From the a Department of Medicine, College of Medicine, University of Mosul, ${ }^{b}$ Department of Medicine, Ibn Sina Teaching \\ Hospital, Mosul, Iraq \\ Correspondence: Khalid N. Al-Khero'. Khalid_kheroo@yahoo.com.
}

(Ann Coll Med Mosul 2013; 39 (2): 160-165).

Received: $8^{\text {th }}$ Aug. 2012; Accepted: $19^{\text {th }}$ May 2013.

\section{ABSTRACT}

Objectives: To assess bone mineral density in $\beta$ - thalassemia major (TM) patients and its relation with gender, age, hemoglobin ( $\mathrm{Hb}$ ), calcium, ferritin, body mass index (BMI), chelation therapy, and splenectomy. Patients and methods: Randomised cross-sectional study of 52 patients with beta thalassemia major (TM) from Thalassemia Center in Ibn-Alatheer Teaching Hospital (32 males and 20 females) with age between 3 and 30 years scanned for bone mineral density (BMD) at lumbar spine with dual-energy X-ray absorptiometry (DEXA) scan at DEXA unit in Ibn-Sena Teaching Hospital from September 2010 to December 2010. The information about chelation therapy and splenectomy were obtained from the patients with measurement of height and weight and blood samples for hemoglobin $(\mathrm{Hb})$, calcium and ferritin were taken.

Results: All 52 patients had T-score in osteoporotic range (100\%), however, Z-score osteoporosis was seen in $26(50 \%)$ and osteopenia in $19(36.5 \%)$. Bone density was normal in only 7 (13.4\%). All patients had elevated ferritin levels (100\%), $36(69.2 \%)$ had low body mass index (BMI) and $32(61.5 \%)$ had low hemoglobin $(\mathrm{Hb})$ levels. Twenty six $(50 \%)$ had low calcium levels and $2(3.8 \%)$ were not using chelation therapy. Sixteen $(30.7 \%)$ had delayed puberty and the rest $36(69.2 \%)$ were in prepubertal stage. Twelve patients $(23 \%)$ had splenectomy.

Conclusion: There is high incidence of low BMD in beta thalassemia ( $100 \%$ by T-score and $86.5 \%$ by Zscore) with significant association with age (P-value0.000), low BMI (P-value 0.038), low Hb (P-value 0.022), delayed sexual maturity ( $P$-value 0.000$)$, and splenectomy ( $P$-value 0.000$)$.

\section{تأثير مرض فقر دم البحر المتوسط نوع بيتا على كثافة العظام في الموصل

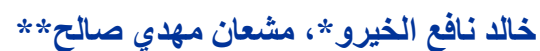$$
\text { *فرع الطب، كلية الطب، جامعة الموصل، **زفرع الطب، مستثفى ابن سينا التعليمي، الموصل، العراق }
$$

الثلاسيميا هو أحد أمر اض الدم الثنائعة والمقترنة بالعديد من المضاعفات طويلة الأمد، ومن هذه المضاعفات المزمنة الكثافة المنخفضة لمعدن العظم (هثاشة العظام). الأهداف: دراسه كثافة معدن العظم في مرضى البيتا ثلاسيميا وعلاقة ذلك مع الجنس والعمر ومستوى الهيمو غلوبين ومستوى (الكالسيوم ومستوى الحديدين (ferritin) ومقياس كتلة الجسم (body mass index) وعلاج إخراج الحديد (chelation) therapy) تصميم البحث: دراسة مقطعية عرضية عشو ائية لـ م ه مريضاً من مرضى فقر دم البحر الأبيض المتوسط نوع بيتا الكبرى. مكان إجراء البحث: مركز الثناسيميا في مستشفى ابن الأثثر التعليمي ووحدة الدكسا في مستشفى ابن سينا البنا التعليمي من أيلول

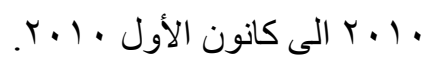

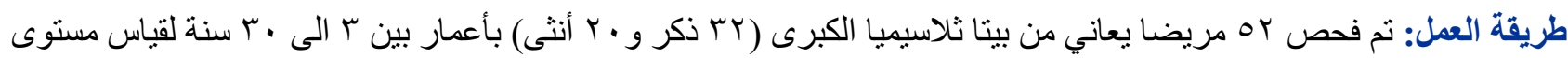

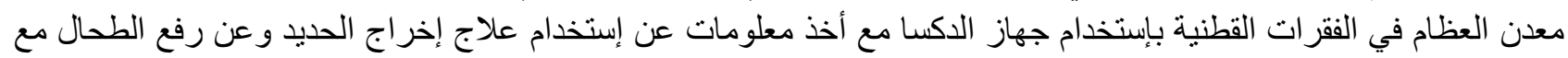

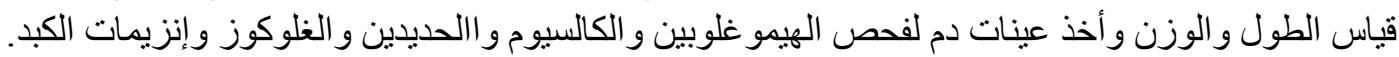

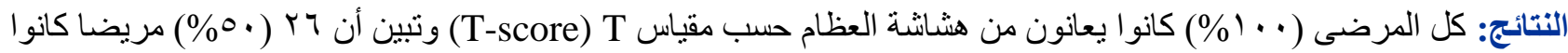

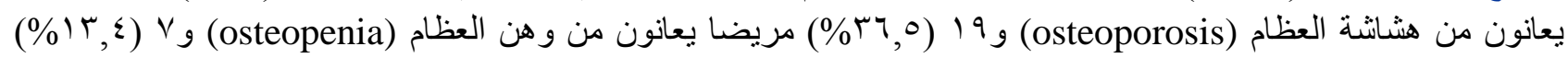




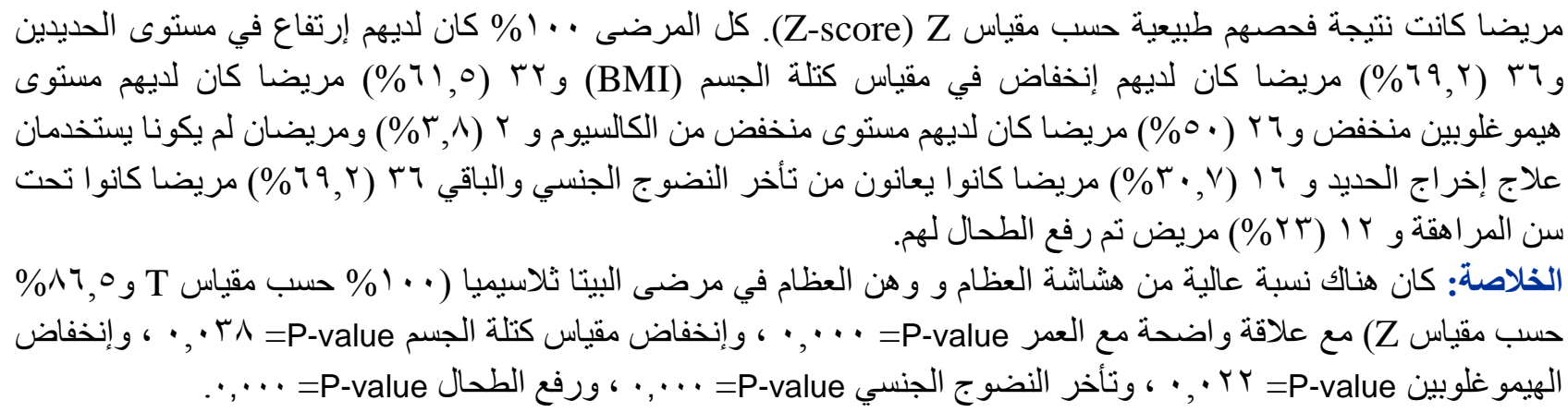

\section{INTRODUCTION}

O steoporosis is a condition of decreased bone mass. This leads to fragile bones which are at an increased risk for fractures. In fact, it will take much less stress on an osteoporotic bone to fracture it than a healthy bone. The term "porosis" means porous, which describes the appearance of osteoporotic bones when they are broken in half and the inside is examined. Normal bone marrow has small holes within it, but a bone with osteoporosis will have much larger holes. ${ }^{1}$ Osteopenia and osteoporosis represent prominent causes of morbidty in patients of both genders with thalassemia. ${ }^{2}$ During the last decade, the presence of osteopenia and osteoporosis in well-treated thalassemics has been described in different studies with high prevalence (up to $50 \%$ ). ${ }^{3}$ Several factors are implicated in reduction of bone mass in TM: delayed sexual maturation, growth hormone (GH and insulin growth factor-(IGF)-1 deficiency), parathyroid gland dysfunction, diabetes, hypothyroidism, ineffective hemopoesis with progressive marrow expansion, direct iron toxicity on osteoblasts, as well as liver disease., Furthermore, iron chelation has correlated with growth failure and bone abnormalities, and high desferrioxamine dosage has been associated with cartilage alterations. ${ }^{3,5,6}$

Bone mineral density (BMD) testing is a widely available clinical tool to diagnose osteoporosis and predict fracture risk. $^{7}$ Dual-energy $X$-ray absorptiometry (DEXA) of the spine, hip and forearm is the best method for diagnosis of osteoporosis and monitoring changes in BMD over time. ${ }^{8}$

Thalassemias are a group of inherited defects in hemoglobin synthesis due to absence or decrease production of alpha or beta globin chains, characterized by ineffective erythropoesis and increased peripheral destruction of red blood cells (RBCs) with reduced life span of RBCs and chronic hemolytic anemia. $^{9}$

\section{Aim of study}

1) To assess bone mineral density (BMD) in patients with beta thalassemia major (TM) and its relation with age, gender, serum calcium and body mass index (BMI). 2) To evaluate the effects of hemoglobin $(\mathrm{Hb})$ and serum ferritin on bone mineral density (BMD). 3) To find out the effects of splenectomy and iron chelation therapy on bone mineral density (BMD).

\section{PATIENTS AND METHODS}

A cross-sectional randomized hospital-based study was conducted at Thalassemia Center in IbnAlatheer Teaching Hospital and DEXA unit in IbnSena Teaching Hospital. A total of 52 patients with beta thalassemia major (TM) (32 males and 20 females) were enrolled in this study from September 2010 to December 2010. Their ages were between 3 and 30 years (Mean age $13 \pm 7.4$ years). The patients according to age were divided into 3 groups $(<10,10$ to 20 and $>20$ years). All patients were scanned for bone mineral density (BMD) at anteroposterior lumbar spine (L1-L4) using dual energy $\mathrm{X}$-ray absorptiometry (Hologic Discovery W(S/N 83909) 1997 USA). The BMD results were expressed as T-score (measures patients BMD against that of a normal, healthy, 30 years old, sex matched) and Z-score (measures BMD compared to a typical, healthy person of same age and sex). The World Health Organization define osteopenia as a score between -1 and -2.5 , and osteoporosis as a score lower than $-2.5^{9}$ Because T-score in all the patients was in the osteoporotic range we could not compare between patients so we used Z-score only. Venous blood samples were obtained for 
hemoglobin ( $\mathrm{g} / \mathrm{L})$, calcium (mmol/L) and ferritin $(\mathrm{ng} / \mathrm{dL})$. All patients had elevated serum ferritin levels, they were divided into 3 groups $(<1000$, 1000 to 2500 and $>2500 \mathrm{ng} / \mathrm{dL}$ ) as $1000 \mathrm{ng} / \mathrm{dL}$ is the recommended target in TM and below 2500 $\mathrm{ng} / \mathrm{dL}$ is associated with less cardiac complications. ${ }^{10,11}$ The height and weight of the patients were measured and information about age, use of iron chelation therapy [desferroxamine (Desferal) subcutaneous infusion], splenectomy and features of sexual maturity were obtained from the patients, their parents or legal guardians. Physical examination and application of Tanner stages of sexual development were also included. $^{12}$

Body mass index (BMI) was calculated from height and weight using the equation: $\mathrm{BMI}=$ Weight $(\mathrm{kg}) /$ Height $\left(\mathrm{M}^{2}\right){ }^{13}$ Patients were divided into 2 groups: low BMI, less than 18.5 (36 (69.2\%) patients) and normal BMI [16 (30.7\%) patients]. Hemoglobin readings were divided into 2 groups: below $95 \mathrm{~g} / \mathrm{L}$ [32 (61.5\%) patients] and above or equal to $95 \mathrm{~g} / \mathrm{L}$ [20 (38.4\%) patients]. Level $95 \mathrm{~g} / \mathrm{L}$ is the level that suppresses erythropoesis usually with minimal iron overload. ${ }^{14,15}$

Patients were considered to have delayed puberty if there was no breast development by 13 years or no menarche for 3 years after breast development in females, and if there was no testicular enlargement by 14 years in males. ${ }^{16}$ According to this definition patients were divided into 2 groups (prepubertal and those with delayed puberty).

Statistical data were analyzed using SPSS software (version 12, SPSS Inc. 2003). T-test was used to compare the means, and association between variables was compared using Pearsons Chi-Square test. P-value less than 0.05 was considered significant.

\section{RESULTS}

Fifty two patients with beta thalassemia major (TM) were screened for osteoporosis by DEXA scan. All patients $(100 \%)$ had a T-score less than -2.5 i.e. osteoporosis (lowest T-score was -6.5 and highest $\mathrm{T}$-score was -3.0$)$. Mean T-score was $-4.7 \pm 0.9$. But with Z-score, there was 7 (13.4\%) normal, 19 $(36.5 \%)$ with osteopenia and 26 (50\%) with osteoporosis (lowest Z-score -4.6 and highest Zscore 0.8 ). Mean Z-score was $-2.2 \pm 1.3$ (total percentage of low BMD 86.5\%) as shown in Table 1.

Of the 52 patients, $32(61.5 \%)$ were males and $20(38.4 \%)$ were females. Table 2 shows no significant difference between males and females in low bone mineral density measured as Z-score. The age of patients was between 3 and 30 years (mean $13 \pm 7.4$ years). For below 10 years age group, there were $18(34.6 \%)$ patients and for those between 10 to 20 years there were $26(50 \%)$ patients and for more than 20 years, there were 8 (15.3\%) patients. Table 3 shows significant association between age and low $Z$-score ( $P$ value 0.000).

Body mass index was low in 36 patients and normal in the rest (lowest $10.3 \mathrm{~kg} / \mathrm{m}^{2}$ and highest $25.3 \mathrm{~kg} / \mathrm{m}^{2}$ : mean of $17.2 \pm 3 \mathrm{~kg} / \mathrm{m}^{2}$ ). Table 4 shows significant association between low BMI and low Z-score ( $P$ value 0.038 )

Table 1. Bone mineral density measured by $T$ and $Z$ scores.

\begin{tabular}{|c|c|c|c|}
\hline T-score & $\begin{array}{c}\text { No. of } \\
\text { patients }\end{array}$ & Z-score & $\begin{array}{c}\text { No. of } \\
\text { patients }\end{array}$ \\
\hline $\begin{array}{l}\text { Normal } \\
(>-1)\end{array}$ & $0(0 \%)$ & $\begin{array}{c}\text { Normal } \\
(>-1)\end{array}$ & 7 (13.4\%) \\
\hline $\begin{array}{l}\text { Osteopenia } \\
(-1 \text { to }-2.5)\end{array}$ & $0(0 \%)$ & $\begin{array}{l}\text { Osteopenia } \\
\text { (-1 to-2.5) }\end{array}$ & $\begin{array}{c}19 \\
(36.5 \%)\end{array}$ \\
\hline $\begin{array}{l}\text { Osteoporosis } \\
(<-2.5)\end{array}$ & $\begin{array}{c}52 \\
(100 \%) \\
\end{array}$ & $\begin{array}{l}\text { Osteoporosis } \\
(<-2.5)\end{array}$ & $26(50 \%)$ \\
\hline Total & $\begin{array}{c}52 \\
(100 \%) \\
\end{array}$ & Total & $\begin{array}{c}52 \\
(100 \%) \\
\end{array}$ \\
\hline
\end{tabular}

Table 2. Relation between Z-score and gender of patients.

\begin{tabular}{lcccc}
\hline \multicolumn{1}{c}{ Z-score } & Males & Females & Total & $\begin{array}{c}P \\
\text { value }\end{array}$ \\
\hline Normal & $\begin{array}{c}6 \\
(18.7 \%)\end{array}$ & $1(5 \%)$ & $\begin{array}{c}7 \\
(13.4 \%)\end{array}$ & \\
Osteopenia & 12 & $7(35 \%)$ & $\begin{array}{c}19 \\
(36.5 \%)\end{array}$ & NS \\
Osteoporosis & $\begin{array}{c}14.5 \%) \\
(43.7 \%)\end{array}$ & $12(60 \%)$ & $\begin{array}{c}26 \\
(50 \%)\end{array}$ & \\
\cline { 1 - 4 } Total & 32 & 20 & $\begin{array}{c}52 \\
(100 \%)\end{array}$ & \\
\hline
\end{tabular}

Table 3. Relation between Z-score and age of patients.

\begin{tabular}{|c|c|c|c|c|c|}
\hline Z-score & $\begin{array}{c}\text { Age < } \\
10 \\
\text { years }\end{array}$ & $\begin{array}{c}\text { Age } 10 \\
\text { to } 20 \\
\text { years }\end{array}$ & $\begin{array}{c}\text { Age > } \\
20 \\
\text { years }\end{array}$ & Total & $\begin{array}{c}\mathrm{P} \\
\text { value }\end{array}$ \\
\hline Normal & $\begin{array}{c}3 \\
(16.6 \%)\end{array}$ & $\begin{array}{c}4 \\
(15.3 \%)\end{array}$ & $0(0 \%)$ & $\begin{array}{c}7 \\
(13.4 \%)\end{array}$ & \multirow{4}{*}{0.000} \\
\hline Osteopenia & $\begin{array}{c}13 \\
(72.2 \%)\end{array}$ & $6(23 \%)$ & $0(0 \%)$ & $\begin{array}{c}19 \\
(36.5 \%)\end{array}$ & \\
\hline Osteoporosis & $\begin{array}{c}2 \\
(11.1 \%)\end{array}$ & $\begin{array}{c}16 \\
(61.5 \%)\end{array}$ & $\begin{array}{c}8 \\
(100 \%)\end{array}$ & $\begin{array}{c}26 \\
(50 \%)\end{array}$ & \\
\hline Total & 18 & 26 & 8 & $\begin{array}{c}52 \\
(100 \%)\end{array}$ & \\
\hline
\end{tabular}


Table 4. Relation between Z-score and body mass index (BMI).

\begin{tabular}{|c|c|c|c|c|}
\hline Z-score & $\begin{array}{c}\text { Low BMI } \\
<18.5 \\
\mathrm{~kg} / \mathrm{m}^{2}\end{array}$ & $\begin{array}{c}\text { Normal } \\
\text { BMI }\end{array}$ & Total & $\begin{array}{c}P \\
\text { value }\end{array}$ \\
\hline Normal & $\begin{array}{c}5 \\
(13.8 \%)\end{array}$ & $\begin{array}{c}2 \\
(12.5 \%)\end{array}$ & $\begin{array}{c}7 \\
(13.4 \%)\end{array}$ & \multirow{4}{*}{0.0380} \\
\hline Osteopenia & $\begin{array}{c}17 \\
(47.2 \%)\end{array}$ & $\begin{array}{c}2 \\
(12.5 \%)\end{array}$ & $\begin{array}{c}19 \\
(36.5 \%)\end{array}$ & \\
\hline Osteoporosis & $\begin{array}{c}14 \\
(38.8 \%)\end{array}$ & $\begin{array}{c}12 \\
(75 \%) \\
\end{array}$ & $\begin{array}{c}26 \\
(50 \%) \\
\end{array}$ & \\
\hline Total & 36 & 16 & $\begin{array}{c}52 \\
(100 \%) \\
\end{array}$ & \\
\hline
\end{tabular}

Mean hemoglobin level was $92.4 \pm 12 \mathrm{~g} / \mathrm{L}$ (lowest reading was $60 \mathrm{~g} / \mathrm{L}$ and highest reading was $113 \mathrm{~g} / \mathrm{L})$. Table $\mathbf{5}$ shows significant association between low hemoglobin level and low Z-score ( $P$ value 0.022 ).

For serum ferritin level, all patients (100\%) had elevated readings (normal range $20-300 \mathrm{ng} / \mathrm{dL}$ in males and $14-150 \mathrm{ng} / \mathrm{dL}$ in females) ${ }^{10,11}$ with lowest reading $411 \mathrm{ng} / \mathrm{dL}$ and the highest reading $7909 \mathrm{ng} / \mathrm{dL}$ (mean 3751.8 $\pm 1937.7 \mathrm{ng} / \mathrm{dL}$ ). Table 6 shows no significant association between elevated serum ferritin and low Z-score.

Serum calcium was found to be low (less than $2.1 \mathrm{mmol} / \mathrm{L})$ in $26(50 \%)$ of patients and normal in $26(50 \%)$ of patients (mean $2.03 \pm 0.1 \mathrm{mmol} / \mathrm{L}$ ) (lowest reading $1.8 \mathrm{mmol} / \mathrm{L}$ and highest reading $2.3 \mathrm{mmol} / \mathrm{L}$ ). There was no significant association between low calcium level and low Z-score as in Table 7.
There were 50 (96\%) patients on chelation therapy and only $2(3 \%)$ patients without chelation therapy. Table 8 shows no significant association between the use of chelation therapy and low bone mineral density (BMD) in Z-score.

For patients with delayed sexual maturity there were $16(30.7 \%)$ patients with delayed puberty and $36(69.2 \%)$ patients in the prepubertal stage: a significant association between delayed puberty and low Z-score ( $P$ value 0.000 ) is shown in Table 9.

Twelve (23\%) patients had splenectomy and 40 (76.9\%) patients were without. Table 10 shows significant association between patients without splenectomy and low Z-score ( $P$ value 0.000$)$.

$A$ significant association was found between splenectomy and elevated serum ferritin level ( $P$ value 0.030 ) as shown in Table 11.

Table 5. Relation between Z-score and hemoglobin level $(\mathrm{Hb})$.

\begin{tabular}{lcccc}
\hline \multicolumn{1}{c}{ Z-score } & $\begin{array}{c}\mathrm{Hb}<95 \\
\mathrm{~g} / \mathrm{L}\end{array}$ & $\begin{array}{c}\mathrm{Hb}>95 \\
\mathrm{~g} / \mathrm{L}\end{array}$ & Total & $\begin{array}{c}\mathrm{P} \\
\text { value }\end{array}$ \\
\cline { 1 - 4 } Normal & $1(3 \%)$ & $6(30 \%)$ & $\begin{array}{c}7 \\
(13.4 \%)\end{array}$ & \\
Osteopenia & 13 & $6(30 \%)$ & $\begin{array}{c}19 \\
(36.5 \%)\end{array}$ & 0.022 \\
& $(40.6 \%)$ & & 26 & \\
Osteoporosis & 18 & $8(40 \%)$ & $(50 \%)$ & \\
\cline { 1 - 4 } Total & $(56.2 \%)$ & 20 & 52 & \\
& $(61.5 \%)$ & $(38.4 \%)$ & $(100 \%)$ & \\
\hline
\end{tabular}

Table 6. Relation between Z-score and serum ferritin.

\begin{tabular}{lccccc}
\hline \multicolumn{1}{c}{ Z-score } & $\begin{array}{c}\text { Ferritin<1000 } \\
\mathrm{ng} / \mathrm{ml}\end{array}$ & Ferritin 1000-2500 & Ferritin>2500 ng/ml & Total & P value \\
\hline Normal & $0(0 \%)$ & $2(11.1 \%)$ & $5(15.6 \%)$ & $7(13.4 \%)$ \\
Osteopenia & $0(0 \%)$ & $8(44.4 \%)$ & $11(34.3 \%)$ & $19(36.5 \%)$ & $\mathrm{NS}$ \\
Osteoporosis & $2(100 \%)$ & $8(44.4 \%)$ & $16(50 \%)$ & $26(50 \%)$ & $52(100 \%)$ \\
\hline Total & $2(3.8 \%)$ & $16(30.7 \%)$ & $32(61.5 \%)$ & \\
\hline
\end{tabular}

Table 7. Relation between Z-score and serum calcium.

\begin{tabular}{|c|c|c|c|c|}
\hline Z-score & $\begin{array}{c}\text { Low } \\
\text { calcium } \\
<2.1 \mathrm{mmol} / \mathrm{L}\end{array}$ & $\begin{array}{l}\text { Normal } \\
\text { calcium }\end{array}$ & Total & $\begin{array}{c}P \\
\text { value }\end{array}$ \\
\hline Normal & $5(19.2 \%)$ & $\begin{array}{c}2 \\
(7.6 \%)\end{array}$ & $\begin{array}{c}7 \\
(13.4 \%)\end{array}$ & \multirow{4}{*}{ NS } \\
\hline Osteopenia & 7 (26.9\%) & $\begin{array}{c}12 \\
(46.1 \%)\end{array}$ & $\begin{array}{c}19 \\
(36.5 \%)\end{array}$ & \\
\hline Osteoporosis & $14(53.8 \%)$ & $\begin{array}{c}12 \\
(46.1 \%)\end{array}$ & $\begin{array}{c}26 \\
(50 \%)\end{array}$ & \\
\hline Total & 26 & 26 & $\begin{array}{c}52 \\
(100 \%)\end{array}$ & \\
\hline
\end{tabular}

Table 8. Relation between Z-score and use of chelation therapy (Desferrioxamine).

\begin{tabular}{lcccc}
\hline Z-score & $\begin{array}{c}\text { No } \\
\text { chelation } \\
\text { therapy }\end{array}$ & $\begin{array}{c}\text { Chelation } \\
\text { therapy }\end{array}$ & Total & $\begin{array}{c}\text { P } \\
\text { value }\end{array}$ \\
\hline Normal & $1(50 \%)$ & $6(12 \%)$ & $\begin{array}{c}7 \\
(13.4 \%)\end{array}$ & \\
Osteopenia & $1(50 \%)$ & $18(36 \%)$ & $\begin{array}{c}19 \\
(36.5 \%) \\
26\end{array}$ & NS \\
Osteoporosis & $0(0 \%)$ & $26(52 \%)$ & $\begin{array}{c}26 \%) \\
(50 \%)\end{array}$ & \\
\cline { 1 - 3 } Total & 2 & 50 & $\begin{array}{c}52 \\
(100 \%)\end{array}$ & \\
\hline
\end{tabular}


Table 9. Relation between Z-score and sexual maturity of patients.

\begin{tabular}{|c|c|c|c|c|}
\hline Z-score & $\begin{array}{c}\text { Prepubertal } \\
\text { stage }\end{array}$ & $\begin{array}{c}\text { Delayed } \\
\text { puberty }\end{array}$ & Total & $\begin{array}{c}P \\
\text { value }\end{array}$ \\
\hline Normal & 7 (19.4\%) & $0(0 \%)$ & $\begin{array}{c}7 \\
(13.4 \%)\end{array}$ & \multirow{4}{*}{0.000} \\
\hline Osteopenia & 19 (52.7\%) & $0(0 \%)$ & $\begin{array}{c}19 \\
(36.5 \%)\end{array}$ & \\
\hline Osteoporosis & $10(27.7 \%)$ & $\begin{array}{c}16 \\
(100 \%)\end{array}$ & $\begin{array}{c}26 \\
(50 \%)\end{array}$ & \\
\hline Total & 36 & 16 & $\begin{array}{c}52 \\
(100 \%)\end{array}$ & \\
\hline
\end{tabular}

Table 10. Relation between Z-score and splenectomy.

\begin{tabular}{lcccc}
\hline \multicolumn{1}{c}{ Z-score } & $\begin{array}{c}\text { No } \\
\text { splenectomy }\end{array}$ & Splenectomy & Total & $\begin{array}{c}\text { P } \\
\text { value }\end{array}$ \\
\hline Normal & $7(17.5 \%)$ & $0(0 \%)$ & $\begin{array}{c}7 \\
(13.4 \%)\end{array}$ & \\
Osteopenia & $19(47.5 \%)$ & $0(0 \%)$ & $\begin{array}{c}19 \\
(36.5 \%)\end{array}$ & 0.000 \\
Osteoporosis & $14(35 \%)$ & $12(100 \%)$ & $\begin{array}{c}26 \\
(50 \%)\end{array}$ & \\
Total & 40 & 12 & 52 & \\
\hline
\end{tabular}

Table 11. Relation between serum ferritin and splenectomy.

\begin{tabular}{|c|c|c|c|c|}
\hline Ferritin & Splenectomy & $\begin{array}{c}\text { No } \\
\text { splenectomy }\end{array}$ & Total & $\begin{array}{c}P \\
\text { value }\end{array}$ \\
\hline $\begin{array}{l}<1000 \\
\mathrm{ng} / \mathrm{dL}\end{array}$ & 2 (1 6.6\%) & 0 & 2 (3.8\%) & \multirow{4}{*}{0.030} \\
\hline $\begin{array}{l}1000- \\
2500 \\
\mathrm{ng} / \mathrm{dL}\end{array}$ & 4 (33.3\%) & $14(35 \%)$ & $\begin{array}{c}18 \\
(34.6 \%)\end{array}$ & \\
\hline $\begin{array}{l}>2500 \\
\mathrm{ng} / \mathrm{dL}\end{array}$ & $6(50 \%)$ & $26(65 \%)$ & $\begin{array}{c}32 \\
(61.5 \%)\end{array}$ & \\
\hline Total & $12(23 \%)$ & 40 (76.9\%) & $\begin{array}{c}52 \\
(100 \%)\end{array}$ & \\
\hline
\end{tabular}

\section{DISCUSSION}

The study showed high incidence of low bone mineral density in beta thalassemia major both in T-score (100\%) and Z-score (86.5\%). The difference between $T$ and Z-scores is expected as most of our patients are children and they would have lower BMD compared with a healthy 30 years control match (i.e. T-score). Also the study showed no significant difference between males and females as far as bone mineral density is concerned. This was in agreement with Karimi, et $a l^{17}$ and Shamshirsaz, et $a l^{18}$, but not with others, ${ }^{19}$ ${ }^{25}$ who reported lower BMD in males. This may indicate more severe changes in females in our study, which could be due to delayed puberty in patients as amenorrhea and hypogonadism have a greater impact on osteoporosis in females than in males. ${ }^{25}$ There was very significant association between low bone mineral density and advanced age. This is in agreement with Christoforidis et $a l,{ }^{20}$ and contrary to others, ${ }^{19,22,23}$ who showed lower bone mineral density in young patients (3-13 years). This may be due to the large number of patients with delayed puberty in our study, as BMD which is already low in childhood, decreases further in patients with absent or delayed puberty. ${ }^{24}$ There was also significant association between low body mass index and low bone mineral density in constrast to Rafsaniani et al, ${ }^{19}$ which may be due to delayed growth caused by chronic anemia (as patients did not follow proper transfusion program), delayed puberty and growth hormone deficiency (which was not measured in our study). There was significant association between low hemoglobin level and low bone mineral density as found by Karimi, et al ${ }^{17}$ but contrary to Rafsaniani et al. ${ }^{19}$ This is mostly due to increased erythropoesis, bone marrow expansion and increased transfusion requirement with lower $\mathrm{Hb}$. There was no significant association between elevated serum ferritin and low bone mineral density as was reported by Rafsaniani, et $a l^{19}$ which may be attributed to the small number of the patients in the study or because all patients had elevated levels so there was no significant difference between them (because it is well known that iron is toxic to osteoblasts). ${ }^{3}$

There was no significant association between low serum calcium and low bone mineral density as found by Rafsaniani, et al. $^{19}$ There was no significant association between no use of chelation therapy and low bone mineral density, most likely due to the limited number of patients not using chelation therapy (only 2 patients), the under dosing of desferroxamine or the harmful effects of chelation therapy on bone (growth failure, bone abnormalities and cartilage alterations). ${ }^{2,4,5}$

There was very significant association between delayed puberty and low bone mineral density, comparable to Saffari et al, ${ }^{23}$ Rafsaniani et al, ${ }^{19}$ Filosa et $a F^{26}$ and Toumba et al..$^{24}$ This is expected because sex hormones have important role in skeletal maturation and preservation in both males and females. ${ }^{25}$

There was very significant association between splenectomy and low bone mineral density which may be due to the fact that older patients usually undergo splenectomy, or because ferritin was significantly elevated in patients with splenectomy and iron has direct toxic effects on osteoblasts, ${ }^{3}$ or 
to other unknown causes, which will need more studies in the future.

\section{CONCLUSION}

1) There was high incidence of low bone mineral density (BMD) in patients with beta thalassemia major (TM) $(100 \%$ by T-score and $86.5 \%$ by $Z$ score). 2) There was significant association between low bone mineral density and older patients ( $P$ - value 0.000$)$, low body mass index ( $P$ value 0.038$)$, low hemoglobin level (P-value 0.022$)$ delayed sexual maturity (P-value 0.000), splenectomy ( $P$ - value 0.000 ), and high serum ferritin (P-value 0.030). 3) There were no significant effects of serum calcium, serum ferritin, and chelation therapy on BMD and gender.

\section{REFERENCES}

1. Evans W. Principles of Operation of DEXA system, University Hospital of Wales, Cardiff Valerie Place Seminar Room, School of Nursing, Trinity Centre for Health Sciences Dublin (Ireland) Wednesday $25^{\text {th }}$ October 2006.

2. Di Stefano M, Chiabotto $P$, Roggia $C$, et al. Bone mass and metabolism in thalassemic children and adolescents treated with different iron-chelating drugs. Journal of bone and mineral metabolism 2004;22(1):5357.

3. Voskaridou E, Terpos F. New insights into the pathophysiology and management of osteoporosis in patients with beta thalassemia. British journal of hematology, 2004; 127(2):127-139.

4. Skordis N, Efstathiou F, Kyriakou A, Toumba M. Hormonal dysregulation bone in thalassemia-an overview. Pediatric endocrinology reviews 2008; 6 (supplement 1):107-115.

5. Olivieri NF, Koren G, Harris J, et al. Growth failure and bony changes induced by deferoxamine. American journal pediatric hematology/oncology 1992;14(1):48-56.

6. De Virgiliis S, Congia M, Frau F, et al. Desferoxamineinduced growth retardation in patients with thalassemia major,Journal of pediatrics 1988;113(4):661-669.

7. Marshall D, Johnell O, Wedel H. Meta-analysis of how well measures of bone mineral density predict occurrence of osteoporotic fractures. BMJ 1996;312: 1254.

8. El Maghraoui A, Roux C. DXA scaning in clinical practice. QJM 2008;101:605.

9. Porter JB. Practical management of iron overload. British Journal of Hematology 2001;115:23-30.
10. Ikram N, Hassan K, Younas M, Amanat S. Ferritin levels in patients of beta thalassemia major. International Journal Pathology 2004;2:71-74.

11. Feingold D. Atlas of pediatric physical diagnosis. $2^{\text {nd }}$ edition. Philadelphia: W.B. Saunders; 1992. p.16-19.

12. Wikipedia. Delayed puberty. [cited August 2010]. Available from: URL:http:Ilwww.wordiq.com/definition.

13. Rehman M, Lodhi $Y$. Prospects and future conservative management of beta thalassemia major in a developing country. Pak J Med Sci 2004; 20(2):105112.

14. Fauci AS, Braunwald E, Kasper DL, Hauser SL, Longo DL, Jameson JL, Loscalzo J. Harrisons princeples of internal medicine. $17^{\text {th }}$ edition. McGraw-Hill Companies, Inc. 2008. Vol 2, Chapter 99.p.640-641.

15. Colledge NR, Walker BR, Ralston SH. Davidson's principles and practice of Medicine. $21^{\text {st }}$ edition. Churchill Livingsone; 2010. Chapter 21.p.806.

16. Colledge NR, Walker BR, Ralston SH. Davidson's principles and practice of medicine. $21^{\text {st }}$ edition. Churchill Livingsone; 2010. Chapter 5. p. 115.

17. Karimi M, Ghiam AF, Hashemi A, Alinejad S. Bone mineral density in beta thalassemia major and intermedia. Indian pediatrics 2007;44:29-32.

18. Shamshirasaz AA, Bekheirnia MR, Kamgar $M$, et al. Bone mineral density in Iranian adolescents and young adults with thalassemia major, Pediatric hematology and oncology 2007; 24(7):469-4.

19. Rafsaniani KA, Razzaghy-Azar M, Zahedi-Shodami L, Vossough P, Modarres A, Taheri N. Bone mineral density in beta thalassemia major and intermedia, correlation with biochemical and hormonal profiles. Iranian journal of blood and cancer 2009; 1(4):121-127.

20. Christoforidis A, Tsatra E, Tsantali H, Koliakos G, Hatzipantelis $E$. Normal lumbar bone mineral density in optimally treated children and young adolescents with beta thalassemia major. Hormones 2007; 6:334-40.

21. Pakbaz Z, Fung E, Sweeters N, Butensky E, Singers $\mathrm{S}$, Vichinsky $\mathrm{E}$, et al. Low bone mass in patients with thalassemia. Pediar Blood and Cancer 2004;42:516.

22. Vogiatzi MG, Autio KA, Schneider R, Giardina PJ. Low bone mass in thalassemia major. J Pediat Endocrinol Metab 2004; 17: 1415-21.

23. Saffari $F$, Abofasl M. Bone mineral density in patients with beta thalassemia major in Qazvin. Journal of Isfahan medical school 2008;26(89):186.

24. Toumba M, Skordis N. Osteoporosis syndrome in thalassemia major: An overview. Journal of osteoporosis 2010; 2010:1-5.

25. Norman J. Making the Diagnosis of Osteoporosis. [Cited 2012]. Available from: URL:http:Ilwww. endocrineweb.com/condition/osteoporosis.

26. Filosa A, Maio S, Vocca S, Saviano A, Esposito G, Pagano L. Longitudinal monitoring of bone mineral density in thalassemic patients. Acta Paediatr 1997; 86(4):342-6. 